\section{Marking the 40 Years of the Revija za sociologiju}

It is forty years since the Revija za sociologiju, the scholarly journal of the Croatian Sociological Association, was launched. This anniversary speaks much of the enthusiasm, expertise and output within the Croatian sociological scholarly community; it also conveys the openness of this community, both geographically and in the disciplinary sense. The successful continuation of the journal is due first of all to numerous contributors whose texts have enabled the Revija za sociologiju to mirror the development of Croatian sociology, to become a place of dialogue of sociologists in Croatia and abroad, as well as of multidisciplinary analysis of social phenomena and processes.

Particular acknowledgement goes to the dedicated and competent work of previous editors and editorial boards, whose editorial concepts enabled the journal to acquire distinction and become rooted in Croatian scholarly publishing. Editorial concepts, though inevitably placed within a socio-historical context with all its limitations have, at the same time, congruently with the critical stance inherent to sociology, at least implicitly, expressed ambition which could be, in Bourdieu's words, described as overcoming "intellectual ethnocentrism" through continuous "epistemological vigilance". Thus, through all former editorial concepts, notwithstand-

\section{Uz 40 godina Revije za sociologiju}

Navršilo se četrdeset godina otkako je počela izlaziti Revija za sociologiju, znanstveni časopis Hrvatskoga sociološkog društva. Obljetnica je to koja svjedoči o entuzijazmu, stručnosti i produktivnosti unutar hrvatske sociološke znanstvene zajednice, ali i o otvorenosti te zajednice prema prekoračivanju granica, kako zemljopisnih tako i disciplinarnih. Postignuti kontinuitet treba ponajprije zahvaliti brojnim suradnicima/ama koji su svojim prilozima pridonijeli da Revija za sociologiju postane svojevrsnim ogledalom razvoja hrvatske sociologije, mjestom dijaloga domaćih i stranih sociologa/inja te multidisciplinarnih analiza društvenih pojava i procesa.

Posebnu zahvalu zavrjeđuje predanost i stručnost dosadašnjih urednika/ ca i uredništava na čijim se uređivačkim koncepcijama časopis profilirao i ukorijenio u hrvatskome znanstvenom izdavaštvu. Uređivačke koncepcije, iako neizbježno društvenopovijesno kontekstuirane sa svim ograničenjima koja otuda proizlaze, istodobno su, sukladno sociologiji inherentnoj kritičnosti, makar implicitno, izražavale ambiciju koja bi se Bourdieuovim riječima mogla opisati kao nadvladavanje »intelektualnog etnocentrizma« stalnom »epistemološkom budnošću«. Tako se kroza sve dosadašnje uređivačke koncepcije, 
ing their particular characteristics, conditioned by the time and place in which they emerged, there runs a universal theme, which could be summarised by the ideas of scientific relevance, dialogue, discernment, polemics, internationalisation and interdisciplinary character.

Therefore, besides expressing our gratitude to them, we should mention the names of the creators of the editorial concepts, starting from the first editors-inchief, Zvonko Lerotić and Josip Obradović (1971-1973), and other members of the first editorial board (Ivan Cifrić, Ruža FirstDilić, Božo Jušić, Ivan Magdalenić, Tena Martinić, Vjekoslav Mikecin, Antun Petak, Dimitrije Sergejev and Ivica Škarić). The next editors-in-chief were: Josip Obradović and Antun Petak (1973-1974), Antun Petak (1974-1976), Ivan Cifrić and Antun Petak (1976-1977), Ognjen Čaldarović and Duško Sekulić (1978-1981), Ognjen Čaldarović (1982-1985), Mladen Lazić (1986-1987), Vjekoslav Afrić (1988-1993), Aleksandar Štulhofer (1993-1995), Jelena Zlatković Winter (1996-2006) and Jasminka Lažnjak (2007-2008). In addition, our current editing and editorial concepts, since 2009, in spite of many changes, continue to be based, to a large degree, on the experiences of our predecessors.

In spite of the confused, poor, and in many ways unfavourably disposed times towards scholarly publishing in which we mark this anniversary, forty years of continuity is sufficient encouragement for further publication and advancement of the Revija za sociologiju. Among the priorities, prominence should be given to increased internationalisation of the contents, authors and editorial team in the journal, and especially of its reviewing procedures. As well as raising the quality of texts and reviewing procedures, polemics and a more uza sve njihove osobitosti uvjetovane vremenom i prostorom u kojem su nastajale, provlači univerzalna poveznica sažeta u idejama znanstvene relevantnosti, dijaloga, kritičnosti, polemičnosti, internacionalizacije $i$ interdiciplinarnosti.

Stoga uz zahvalu treba spomenuti i imena tvoraca uređivačkih koncepcija, počevši od prvih glavnih urednika, Zvonka Lerotića i Josipa Obradovića (1971-1973.), te ostalih članova/ica prvoga uredništva (Ivan Cifrić, Ruža FirstDilić, Božo Jušić, Ivan Magdalenić, Tena Martinić, Vjekoslav Mikecin, Antun Petak, Dimitrije Sergejev i Ivica Škarić). Sljedeći su glavni urednici/e bili: Josip Obradović i Antun Petak (1973-1974.), Antun Petak (1974-1976.), Ivan Cifrić i Antun Petak (1976-1977.), Ognjen Čaldarović i Duško Sekulić (1978-1981.), Ognjen Čaldarović (1982-1985.), Mladen Lazić (1986-1987.), Vjekoslav Afrić (1988-1993.), Aleksandar Štulhofer (1993-1995.), Jelena Zlatković Winter (1996-2006.) te Jasminka Lažnjak (2007-2008.). I svoj urednički rad te uređivačku koncepciju od 2009., unatoč brojnim promjenama, umnogome nastavljamo na iskustvima prethodnika.

Unatoč konfuznom, siromašnom i znanstvenome izdavaštvu višestruko nesklonom vremenu u kojem obilježavamo ovu obljetnicu, četrdesetogodišnji kontinuitet dovoljno je snažan poticaj za nastavak publiciranja i daljnje unapređivanje Revije za sociologiju. Među prioritetima treba istaknuti daljnje intenziviranje sadržajne, autorske i uredničke internacionalizacije časopisa, a osobito njegova recenzijskog postupka. Osim podizanja kvalitete priloga i recenzijskoga postupka, poticat će se polemičnost $\mathrm{i}$ 
vivid scientific dialogue connected to the theoretical, methodological and research issues of sociology and related disciplines should be encouraged. In this connection, we should remember the necessity for publishing and affirming sociological research important for understanding Croatian society and which, through its actuality and scientific relevance, contributes to the advancement of the discipline and also to the Croatian scientific language in the field of sociology.

An ongoing task remains enhancement of the visibility of the Revija $z a$ sociologiju in the international scholarly community. One of the changes in this direction is of a technical nature, and refers to introducing a digital identifier for each published text (DOI) and entering the CrossRef organisation. By facilitating electronic accessibility to the texts, DOI has become one of the demands of the contemporary scientific communication.

Finally, the aim of the Revija za sociologiju is to contribute to the improvement of scientific communication, both through the quality of the published papers, dispersion of the results of theoretical and empirical research, and through editorial rigour. uspostavljanje življega znanstvenog dijaloga vezanog uz teorijske, metodološke $\mathrm{i}$ istraživačke probleme sociologije $\mathrm{i}$ srodnih disciplina. Pritom će se imati na umu i potreba publiciranja te afirmacije socioloških istraživanja koja su važna za razumijevanje hrvatskoga društva, a po svojoj aktualnosti i znanstvenoj relevantnosti pridonose razvoju discipline i hrvatskoga znanstvenog jezika struke.

Trajnom zadaćom ostaje i povećavanje vidljivosti Revije za sociologiju u međunarodnoj znanstvenoj zajednici. Jedna od promjena $u$ tome smjeru tehničke je naravi, a odnosi se na uvođenje digitalnih identifikatora za sve objavljene tekstove (DOI) i pristupanje organizaciji CrossRef. Time što olakšava elektroničku dostupnost tekstova, DOI postaje jednim od zahtjeva suvremenoga znanstvenog komuniciranja.

Najposlije, namjera Revije za sociologiju i jest da pridonese unapređivanju znanstvenoga komuniciranja, kako kvalitetom objavljenih priloga, rezultata teorijskih i empirijskih istraživanja, tako i uredničkom rigoroznošću.

Jadranka Čačić-Kumpes glavna urednica / Editor 